\title{
Consent, Consensus and the Leviathan: A Critical Study of Hobbes Political Theory for the Contemporary Society
}

\author{
Moses O. Aderibigbe \\ General Studies Department, School of Sciences, Federal University of Technology, Akure, Nigeria \\ Email: mosesaderibigbe@yahoo.com
}

Received 26 February 2015; accepted 15 August 2015; published 18 August 2015

Copyright (C) 2015 by author and Scientific Research Publishing Inc. This work is licensed under the Creative Commons Attribution International License (CC BY). http://creativecommons.org/licenses/by/4.0/ (c) (i) Open Access

\begin{abstract}
The purpose of the state and its apparatus right from the formation of human society to this contemporary period is still being confronted with the question of legitimacy. One of the major reasons why the state is formed is for the attainment of good life of the citizens. The institution of the state would thus remain legitimate only when those who are in political authority perform basic functions of government to meet the expectations of the members of the society. To this end, this paper examines the concept of consent and consensus as a foundation for the justification of the emergence of the state and argue that if there is no mutual agreement within the society, there can be little or no way of ensuring peaceful resolution of policy differences that is associated with the democratic process. Consequent upon this, the paper adopts Thomas Hobbes social contract theory as a theoretical framework to explain the origin of the state and justify the absolute power of the government which is rooted in the consent and the consensus of the people. The philosophical methods of conceptual clarification and critical analysis are employed to examine Hobbes political theory and evaluate its relevance to the contemporary society.
\end{abstract}

\section{Keywords}

State, Legitimate, Consent, Consensus, Contract

\section{Introduction}

Hobbes was one of the social contract theorists that explain the nature of public power as a special kind of institution. His theory of the state deserves a careful consideration since it is one of the modern political theories. However his political theory is set to achieve at least two purposes. One is to explain the origin of the state, and 
the other is to justify absolute and unlimited power of the government. Hobbes' political philosophy, however, is viewed by some scholars as liberal and some as non-liberal. It is said to be liberal on one hand because he derives or explains the existence of society and the state by reference to "free and equal" individuals. He uncovered the best circumstances for human nature, which he sees as naturally selfish, egoistic and self-interested. Also, he emphasizes the importance of consent in the making of a contract or bargain, not only to regulate human affairs and secure a measure of independence and choice in society, but also to legitimize, such regulation. Yet, on the other hand, Hobbes' position is said to be non-liberal since his political conclusions emphasize the necessity of a practically all-powerful state to create laws and secure the conditions of social and political life (Held, 1984).

The concept of consent and consensus can be seen as a foundation upon which Thomas Hobbes built his justification of the emergence of the Leviathan, and the duty of institutional obedience derives from the fact that citizens have consented or agreed to do so. This paper argues that if there is no consensus within society, there can be little or no way of ensuring peaceful resolution of policy differences that is associated with the democratic process. Equally, the paper further argues that, for the democratic society to work effectively there has to be a degree of consensus concerning the fundamental values of that society shared by the competing groups.

However, various criticism and objections have been advanced against Hobbes' position; an attempt shall be made in this work to evaluate some of them with the aim of suggesting some plausible solutions. The paper equally attempts to critically assess Hobbes idea of consent and consensus in relation to the emergence of the Leviathan. Effort shall be made to look at the relevance of his theory on the contemporary state.

\section{The State of Nature and the Nature of Man}

Hobbes begins his political theory from the description of human nature in the state of nature. Having been influenced by Galileo whose scientific principles indicates that mechanical laws are determined and that everything within the universe is in motion; these thus, influenced his analysis of man's nature. Hobbes holds that appetite and aversion are parts of men's abnormal' nature, which cause each man to seek his own goal, his selfpreservation in whatever he engages in and these goals are determined by the will, appetite, and aversion (Hobbes, 1651).

Hobbes contends that happiness or felicity consists in a continual progress of the desire from one object to another and since this is so, what men seek constantly is some means of securing the way to their future desires. Men seek not only to procure, but also to be ensured of a contented life for themselves. He therefore expressed it thus "in the first place, I put for a general inclination of all mankind, a perpetual and restless desire of power after power that ceaseth only in death" (Strauss \& Cropsey, 1987).

Man, according to Hobbes seeks power for security and self preservation and men are bound to conflict since they are individualistic in their selfish quests to acquire more power and scarce material bounties of nature than others. Hence, men go to war because of their desire for power. Two men want something, which they cannot both have, Hobbes maintained, they become enemies and endeavor to subdue and destroy one another. Given this, Hobbes identified three great natural causes of quarrels among men in the state of nature. These are competition, distrust and glory. These make the state really a state of war, "and such a war, as is of every man, against every man” (Macpherson, 1968). He noted that:

Men live without other security, than what their own strength, and their own invention shall furnish them withal. In such condition there is no place for industry; because the fruit thereof is uncertain: and consequently no culture of the earth. no navigation, no commodities no commodious building; no instruments of moving and removing such things as required much force; no knowledge of the face of the earth; no account of time; no arts; no letters; no society; and which is worst of all, continual fear, and danger of violent death; and the life of man solitary, poor, nasty, brutish, and short (Strauss \& Cropsey, 1987).

Furthermore, the state of nature was characterized with injustice there is no appeal to justice and nothing there can be unjust, since the concept of justice and injustice can only be meaningful within a society and when there is a common power. The absence of a common power therefore implies the absence of law; and where there is no law, there is no injustice.

The two cardinal virtues, according to Hobbes, are "force" and "fraud", deceit and falsehood are also among the virtues recognized in the state of nature. Hobbes having held unto Thrasymachian model of the positivist theory of justice insisted that justice is what the ruler shall determine it to be and in the pre-social state there is 
no ruler.

So also, in the natural state according to Hobbes, "there is no property, no dominion, no mine and thine; but only that to be everyman's that he can get, and for so long as he can keep it” (Molesworth, 1962). The picture of man as portrayed by Hobbes depicts him as a being that is only being governed by instincts, drives by passions, egoistic and self-centered, thus, he is always in the state of conflict with his fellows.

Now, looking at the other side in the state of nature, Man is said to be a rational being and therefore can reason and this is what distinguishes him from other animals. His passion and reasoning ability in the natural state was the only thing he possesses that can make him get out of the bad condition, the departures which will be a lasting benefit to everyone. Hobbes finds it convenient to ascribe the ability of reason to men while in fact in his human nature; he says that man is an animal guided by passions:

The passion that incline men to peace, are fear of death; desire of such things as are necessary to commodious living; and a hope by their industry to obtain. And reason suggesteth convenient articles of peace, upon which men may be drawn to agreement (Molesworth, 1962).

The kinds of passion that are in men's mind are prone to always be making war on each other unless they are restricted by some power. And the strongest of these passions is the fear of death. Reason, working along with these passions of fear, desire and hope, now suggests rules for peaceful co-existence. In the state of nature, men have natural rights and these rights guaranteed the liberty everyone has to protect his life, a man is free to do whatever he chooses to in order to achieve the goal of self-preservation. But again, there is the law of nature which is quite different from the rights of nature. These are precepts of reason which instruct men as to what they ought to do to avoid the perils, to their own self-preservation that follow equally from their natural rights and from their irrational desires.

Hobbes defines it as:

Those precepts or rules which are grounded on reason, by which a man is forbidden to do that, which is destruction of his life, or taken away the means of preserving the same, and to omit that, by which he thinketh it may be best preserved (Molesworth, 1962).

Hobbes calls these the precepts or "the maxims of prudence" and sometimes, he says they are "commands of God". These precepts or rules are not created by human government, rather they exist in the state of nature and they are constitutive and regulative principles which form the basis of society that emerged from the state of nature.

Two of these laws are fundamental, fundamental because Hobbes believes that they are eternal and immutable (Irele, 1998). The first law of nature enjoins men to seek peace and to defend themselves against those from whom peace cannot be obtained. In a better way Hobbes stated it thus:

That everyman, ought to endeavour peace, as farre as he has hope of obtaining it and when he cannot obtain it, that he may seek, and use, all helps, and advantages of Warre (Macpherson, 1968).

This law prescribes peace as a condition of security.

The second law equally maintains:

That a man be willing when others are so too, as farre-forth, as for peace and defense of himself he shall think it necessary, to lay down his right to all things; and be contented with so much liberty against other men, as he would allow other men against himself (Macpherson, 1968).

The first law that suggested the need for endeavoring peace might be the result of this second law which allows men to consider it reasonable to mutually relinquish their right of self-preservation to a common power who will keep peace in the interest of all. This mutual way through which people laid down their rights is what has come to be known as the social contract.

As regards the state of nature, in which men, being what they are would necessarily behave as if there were no authority to enforce law, yet, in this same state there was the recognition of the fact of the shortness of time which brought about certain laws, these laws enjoined men to seek peace and to mutually relinquish their right to a common power. There were some agreements reached by consensus among the people themselves to seek for each other's peace and as well to relinquish their individual rights to a common power. 


\section{Social Contract by Consent and the Emergence of Leviathan}

The transitional stage from the Hobbesian state of nature to the emergence of an all-powerful Leviathan or commonwealth is what is known as the social contract. And it is from this transfer of power and rights of the individual by consent to a Leviathan that political power evolves. Although, according to Hobbes the requisite sovereign power might come into existence in either of two ways: by some man or body or men conquering and subduing the inhabitants (Sovereignty by acquisition) or by men agreeing by consent with each other to transfer all their natural powers to some man or body of men (Sovereignty by institution) (Macpherson, 1968).

Hobbes was aware that the logical outcome of egotistical, competitive, and self preservative individuals all deciding how best to survive would lead to a state of anarchy and to avoid such a condition of anarchy is for men to give up their natural rights which are contrary to peace and enter into agreement with each other as if every man should say to everyman, I authorize and give up my right of governing myself, to this man, or to this assembly of men, on this condition, that thou give up thy right to him, and authorize all his actions in like manner (Stumpf, 1994).

Every man was expected to submit their individual rights (except that of self-preservation) and recognize the common instituted power. Hobbes expressed it thus:

The only way to erect such a common power as may be able to defend them from... injurious of one another. and thereby to secure them in such sort, as that by their own industries, and by the fruites of the earth, they may nourish themselves and live contentedly is, to conferre all their power and strength upon one man, or upon one Assembly of men, that may reduce all their wills by plurality of voices, unto one will (Macpherson, 1968).

Hobbes demonstrated logically that sovereign power is indivisible since in the state of nature anarchy was the logical consequence of independent individual judgments. He therefore concluded that the only way to overcome such anarchy is to make a single body out of the several bodies of the citizens. To transform multiple wills into a single will is to agree that the sovereign's single will and judgment represent the will and judgment of all the citizens. In effect this is what the contract is all about and stands for.

However, one thing is obvious in this contract, namely the parties to the contract are individuals who promise each other to hand over their right to the sovereign: it is not a contract between the sovereign and the citizens. The sovereign has absolute power to govern and is in no way subject to the citizens. It should be noted that the Leviathan is not a party to the agreement or contract, this means that the sovereign makes no promises, since he is to have absolute authority, his rights must not be limited by any contractual obligation. Hobbes maintained that the sovereign is subject only to the laws of nature; an absolute sovereign authority fulfils the purpose and intent of preventing the conditions that existed prior to the social contract.

Moreover, Hobbes asserted that once the majority of the people have consented to submit their rights to the common power-the Leviathan, the minority of the people cannot have a right to dissent. In His words

...because the major part hath by consenting voices declared a soveraigrie; he that dissented must now consent with the rest; that is. contended to avow all the actions he shall do or else justly be destroyed by the rest... (Macpherson, 1968).

Total and absolute obedience is expected of the subjects after the social contract. Hence there is no right to dissent; the minority must join the majority's opinion. Resistance to sovereign by a citizen is illogical to Hobbes. In the first instance, it would amount to resistance to himself and secondly to resist is to revert to independent judgment, which is the experience in the state of nature. Therefore, the power of the sovereign according to Hobbes must be absolute in order to secure the conditions of order, peace and law which are the major aim of instituting the commonwealth. At this juncture, it must be noted that the key point for Hobbes is that the authority of the state is justified. It is justified on the premise that citizens have consented or agreed to accept this authority. In virtue of this agreement, citizens are now bound to obey. But there is a problem with this conclusion, for instance, it can be critically pointed out that very few people have "consented to" or "contracted with" the sovereign to obey his law, then, why should the contract to which the original contractors consented to be binding on their descendants? F. A. Adeigbo (1995) observes some possible ways to tackle this criticism as put forward by some philosophers.

The first way according to him is to admit that few people, if any, have been known to give their antecedent consent to their government, but then, to insist that the consent answer is really only a recommendation that 
many more ought to do so. He maintained that the consent-answer recommends that the structure of rights and duties, authority and obligation should be patterned on the willing cooperation of all members of the body politics. The task for anyone who accepts this interpretation will now be to show that there are genuine advantages to be derived from acting on the recommendation. Another way of meeting the criticism as he observe, is to maintain that in fact quite a large portion of the population have consented to their government and that a contrary impression has resulted from a narrow (unwarranted) construal of the notion of consent. Only that anyone taking this line of defense will, then, be faced with the task of specifying either the meaning of consent or some variant of that notion. This he be1ieves is the approach taken by Hobbes as he postulated about the "signs of consent by inference", derived in Locke's notion of "tacit consent", by Sesonke, who writes about "the commitments we make by our continuity membership in a community” and by Peter Singer in his notion of "quasiconsent" (Adeigbo, 1995).

Furthermore, on the question "why ought I to obey the government?" the consent theorists, belief that you ought to obey the government because you have consented. It may be objected. I was born into society and have given no explicit promise to obey. The theorist expresses, having resided within its domain, accepted its benefits and participated in its processes, you have tacitly promised to obey government. Objection may still be raised, if that is true, then most Germans were obligated to obey Hitler. The theorist objects. "No, there are limits to consensual obligations. It is asked what limits? Confusion ensues...” (Kann, 1978).

Mark Kann's summary is an exposition of John Locke’s theory of "tacit consent”. His words: ... having resided within its domain, accepted its benefits and participated in its processes as used above is a tacit promise or consent to obey the government. This doctrine is establishing the fact that a silent man may be taken to have consented, but can we justify this kind of consent due to inaction or passivity? There cannot be an obligation without overt signs. In addition, another approach to tacit consent is that once an individual is born into the society, such an individual becomes part and parcel of that society. Hence, he is said to have assumed an obligation because it is as if he has consented to it. This also may not hold because justification for any obligation must be something other than that above. If a man does not make use of any form of word or sign that would conventionally be called promising, we cannot attribute to him the undertaking of an obligation. What follows from this is that hypothetical consent of Locke's type does not render obedience obligatory. Whereas in Hobbes opinion the consent which is relevant to the use of obligation as a conduct-guiding concept need not be always antecedent; it may be, and often is consequent. That is, it may be a consent which is after the fact-a consent which arises from showing that there are good reasons for feeling obligated or for being under an obligation ... thus it suffices that a person behaves in a way that leads others reasonably to presume consent on his part (Adeigbo, 1995).

The law can therefore be obeyed whether or not one was at the place of consensus since there are good reasons for being under an obligation. An individual would be justified in assuming consent once one has accepted the benefits of a mutually cooperative scheme. However, the versions of some recent adherent political philosophers on consent theory vary considerably. Vong (2008) noted that Horton John and Peter Steinberger on one version, accepts the claim that only express consent can generate a political obligation, but calls for political societies to establish formal procedures for evoking such consent. That is, states should require their members openly to undertake an obligation to obey the law or refuse to do so. Those who decline the obligation will then have the options of leaving the state, seceding to form a new state with like-minded people, or taking residence in a territory within the state reserve for dissenters. The implication of this position appears to follow that of the a posteriori philosophical anarchist. The second version of argument is that critics of consent theory construe it too narrowly. They maintained that voting or otherwise participating in elections should count as consent. Also, other activities like calling the police or fire department for help, sending children to public school, using public library and so on constitute active participation in the institution of the state. The point here is that as long as an individual is benefitting from the state such has an obligation to obey.

Again, a critical look at the argument on the natural laws and rights which are acquired in the state of nature reveals certain difficulties. These laws in the proper sense are left unexplained, how do they systematically come about them? The laws of nature that seem to be natural laws are not so, the reason being that they are based not on morals but on prudence, which is due to the condition that existed in the state of nature. These laws therefore are said to be prudential facts merely because men are psychological egoists. Hobbes' claims that man is a-social and that he is totally egoistic. The question now is, is man truly as Hobbes portrayed him? To what extent can we say that human nature is being egocentric and a-social? The fact remain that a man in addition to being 
egoistic also manifests altruistic tendencies; it is not all our actions that arise from selfish motives. We do act altruistically, and also impartiality features prominently in our dealings with others. Men can act impartially, and they can be benevolent on many occasions and our language does reflect this fact (Irele, 1998). In fairness to Hobbes, men are motivated by their desires, but it does not mean or follow that all desire is egoistic. Men sometimes may desire families, children and even their country.

Furthermore, in order to avert anarchy due to the egoistical individuals all deciding how best to survive. Hobbes postulates an absolute sovereign ruler, but then, could this not throw up a tyrant or an authoritarian personality who will trample upon the freedom of the people? Bertrand Russell on this note maintained that in time of war there is a unification of interests, especially if the war is fierce; but in time of peace the clash may be very great between the interests of one class and those of another. Thus, it is not by any means true that in such situation the best way to avert anarchy is to preach the absolute power of the sovereign (Russell, 1995). The fact that the absolute sovereign ruler remains a human being there may be the possibility of power abuse, which may not be in the interest of the people.

A close look at the word contract to explain the government according to this theory demands some critical analysis. Contract from a legal term has meaning only within the context of government. If the state, the law and all legal apparatus therefore only come into existence when government is in place, then contract cannot come into existence without government, and therefore the contract could not have come first. Hobbes therefore should have probably used the word social agreement rather than social contract considering the legal terms of contract.

The Leviathan who is said to be a third-party beneficiary according to Hobbes may-also pose some difficulties of political instability. How can we hold a party liable for breaching an agreement which he is not a party to? On this note Douglas Husak (1979) opined that, it is unclear how a person can be wronged by breach of an agreement to which he has contributed no consideration. Leviathan's independent involvement is questionable; Hobbes notion of all powerful Leviathans would not be acceptable to this contemporary society where collective participation in governance is the order of the day.

At this juncture, in spite of the above various criticisms raised against Hobbes theory, the relevance of his theory for the contemporary society cannot be overemphasize. Hobbes made a strong argument on how we can understand both politics and morality. He justified this position on the premise that there was an agreement between the self-interested and yet rational individuals. This implies that rationality is a force strong enough to give persons internal reason to cooperate in any given society. It is on this note David Gauthier (1986) improves upon Hobbes' argument, given its relevance to the contemporary society that we can establish morality without the external enforcement mechanism of the Sovereign. Gauthier believes that rationality alone convinces persons not only to agree to cooperate, but to stick to their agreement, "moral by agreement” are therefore created out of the rationality of exclusively self-interested agent.

\section{Conclusions}

This paper set out by looking at how Thomas Hobbes began his theory from the nature of man in the state of nature. It examines human predicament which is largely due to the egoistic nature and attitude disposed by all men. Hobbes believes in the state as a means to curb man's excess freedom, to put a stop to the war of every person fighting against the other. The key point for Hobbes is that the authority of the state is justified; this is because the citizens have consented or agreed to accept the authority. In virtue of this agreement, citizens are therefore bound to obey. The concept of consent and consensus can therefore be seen as background upon which the justification of the legitimacy of the sovereign is based. Although, it has been observed that Hobbes theory reflects the situation of his time especially the strife in his society that tore apart the fabric of the society which he wanted to avert, yet, there is a relevance of his theory to the contemporary society. David Held asserted that in Hobbes opinion, while sovereignty must be self-perpetuating, undivided and ultimately absolute, it is established by the authority conferred by the people: The sovereign's right of command and the subjects duty of obedience is the result of consent. Although, there are some things about Hobbes' conception of state which today we would find useful, yet his position is in support of those who argue for the importance of government by consent and reject the claims of the "divine right of kings" and more generally, the authority of tradition (Held, 1984).

Above all, this paper emphasizes the role of unanimous collective agreement in managing conflicts, which are said to be endemic within the liberal democracy. It stresses that for the democratic society to work effectively in 
today's world; efforts must be made to promote unanimous agreement on conflictual issues. This will help the citizens not only to cooperate, but also to stick to their agreement.

\section{References}

Adeigbo, F. A. (1995). The State, the Social Contract Theory and the Doctrine of Estoppel. Journal of Philosophy and Development, 1 , 49.

Gauthier, D. (1986). Morals by Agreement (p. 275). Oxford: Oxford University Press.

Held, D. (1984). Central Perspectives on the Modern States. In Political Theory and the Modern State (p. 90). London: Oxford Blackwell, Ltd.

Hobbes, T. (1651). Leviathan or the Matter, Forme, and Power of a Commonwealth: Ecclesiastical and Civil (Chp. 6, p. 23). London.

Husak, D. (1979). Sovereign and the Third Party Beneficiary. Journal of Value Inquiry, xiii, 150.

Irele, D. (1998). Introduction to Political Philosophy (p. 41). Ibadan: University Press.

Kann, M. (1978). Dialectic of Consent theory. The Journal of Politics, 40, 386-387. http://dx.doi.org/10.2307/2130093

Macpherson, C. B. (Ed.) (1968). Hobbes’s Leviathan (p. 184). Harmondsworth: Pelican Books.

Molesworth, W. (Ed.) (1962). Leviathan: English Works of Thomas Hobbes 111 (p. 74). London: John Bohn.

Russell, B. (1995). A History of Western Philosophy (p. 540). London: Routledge.

Strauss, L., \& Cropsey, J. (1987). History of Political Philosophy (3rd ed., p. 400). London: The University of Chicago Press.

Stumpf, S. E. (1994). Philosophy History and Problems (5th ed., p. 231). New York: McGraw-Hill, Inc.

Vong, G. (2008). In Defense of Kant's Moral Prohibition on Suicide Solely to Avoid Suffering. Journal of Medical Ethics, 34, 655-657. http://dx.doi.org/10.1136/jme.2007.021410 